\title{
SEJARAH DAN PERANAN TARI KANG POTRO DALAM MELESTARIKAN NILAI-NILAI BUDAYA LOKAL (STUDI KASUS DI DESA BANYUDONO KECAMATAN PONOROGO KABUPATEN PONOROGO \\ TAHUN 2006-2012)
}

\author{
Zulfa Khoirun Nisa'* \\ Yudi Hartono*
}

\begin{abstract}
Abstrak
Penelitian ini bertujuan untuk mengetahui sejarah perkembangan, peranan Tari Kang Potro dalam melestarikan nilai-nilai budaya lokal di Desa Banyudono Kecamatan Ponorogo Kabupaten Ponorogo, serta upaya masyarakat dalam melestarikan Tari Kang Potro sebagai produk budaya yang mencerminkan segala aspek kehidupan yang berada didalalmnya. Jenis penelitian studi kasus, Sumber data yang digunakan adalah sumber data primer dan sekunder. Teknik pengumpulan data yang digunakan adalah teknik observasi, wawancara, dan dokumentasi, sedangkan teknik keabsahan data menggunakan triangulasi sumber dan teknik. Analisis data dalam penelitian ini menggunakan model interaktif tiga komponen Miles dan Huberman.

Hasil penelitian ini menunjukkan bahwa nama Tari Kang Potro secara historis berasal dari nama tokoh Potro Joyo-Potro Tholo, dua abdi pengikut Pangeran Bujangganom. Berangkat dari cerita inilah Tari Kang Potro diciptakan, dan mengalami perkembangan dari tahun ke tahun. Tarian ini tidak hanya berperan sebagai tontonan, namun juga menjadi sarana penyebaran informasi efektif untuk mendidik masyarakat melalui nilai-nilai budaya lokal yang terkandung di dalamnya. Upaya pelestarian Tari Kang Potro terus dilakukan oleh masyarakat maupun pemerintah, dengan cara mendirikan Sanggar Tari, mengikutkan tarian ini dalam event-even tertentu, dan mendokumentasikan dalam bentuk $C D$.
\end{abstract}

\section{Kata Kunci: Tari Kang Potro, Pelestarian, Nilai-Nilai Budaya}

Pendahuluan

Indonesia merupakan sebuah negara kepulauan yang mempunyai keanekaragaman kebudayaan dalam masyarakat. Menurut Koentjaraningrat (1990:180), kebudayaan merupakan keseluruhan sistem gagasan, tindakan, dan hasil karya manusia dalam kehidupan masyarakat yang diperoleh dengan cara belajar. Suatu kebudayaan dapat dirumuskan sebagai seperangkat kepercayaan, nilai-nilai dan cara berlaku atau kebiasaan yang dipelajari dan yang dimiliki bersama oleh suatu kelompok masyarakat.

Salah satu unsur universal dalam kebudayaan adalah kesenian. Kesenian umumnya mengacu pada nilai keindahan (estetika) yang bersal dari ekspresi hasrat manusia akan keindahan yang dinikmati dengan mata ataupun telinga (Abraham, Soebijantoro, M. Hanif, Yudi, 2009: 23). 
Manusia sebagai makhluk yang mempunyai cita rasa tinggi, menghasilkan berbagai corak kesenian daerah mulai dari yang sederhana hingga yang kompleks. Kesenian daerah yang memiliki pengaruh dominan terhadap perkembangan budaya bangsa adalah kesenian daerah yang menjadi kebanggaan masyarakat pemilik atau pendukungnya dan mencerminkan identitas daerah. Kesenian Reog dari Ponorogo, Remo dari Surabaya, Kecak dari Bali, dan Gandrung dari Banyuwangi tetap hidup dan mendapat dukungan dari Negara maupun masyarakat pemiliknya karena kesenian tersebut memberi kontribusi yang berarti bagi identitas lokal dan nasional.

Di era globalisasi dewasa ini, melalui teknologi komunikasi yang kian canggih dan cepat dalam menyebarluaskan informasi, semakin memperluas pilihan arah bagi generasi muda. Globalisasi dengan segala mekanismenya telah membukakan pintu yang sangat luas bagi generasi muda Indonesia untuk memandang dunia, memilih, mengambil, dan menginginkan cara-cara hidup yang dipandang sesuai (Bambang dan Iwan, 2009:181). Salah satu pengaruh globalisasi tersebut diantaranya dalam bidang budaya, melahirkan persaingan terbuka antara kebudayaan lokal dengan kebudayaan asing. Tradisi dan kesenian daerah yang pada awalnya dipegang teguh, di pelihara dan dijaga keberadaannya oleh setiap suku, kini sudah hampir punah.

Generasi muda sebagi elemen penting dalam melestarikan kesenian khas daerah, lebih memilih untuk menampilkan dan menggunakan kesenian asing daripada kesenian yang berasal dari daerahnya sendiri. Pada umumnya mereka merasa gengsi dan malu apabila masih mempertahankan dan menggunakan kesenian daerah, karena dianggap kuno atau ketinggalan zaman. Tanpa mereka sadari bahwa sesungguhnya kesenian lokal merupakan jati diri bangsa yang mencerminkan segala aspek kehidupan yang berada didalalmnya. Dengan kata lain kesenian daerah merupakan salah satu kekayaan yang sangat benilai karena selain merupakan ciri khas dari suatu daerah juga mejadi lambang dari kepribadian suatu bangsa atau daerah.

Dampak buruk globalisasi terhadap produk-produk kesenian lokal terus berlanjut, gelombang perubahan yang melanda dunia mencuatkan produk-produk kesenian global yang menghibur, mudah dicerna, gampang ditiru, enak dirasakan, disebarluaskan oleh media massa, dan didukung oleh 
modal besar, merupakan salah satu faktor penyebab ketersudutan kesenian lokal (Ayu Sutarto, 2004: 2). Misalnya kesenian tradisional Wayang, kini tampak sepi seolah-olah tak ada pengunjungnya. Hal ini sangat disayangkan mengingat wayang merupakan salah satu bentuk kesenian tradisional Indonesia yang kaya akan pesan-pesan moral, dan merupakan salah satu agen penanaman nilai-nilai moral yang baik. Lain halnya dengan kesenian asing seperti: balet, gangnam style, dan harlem shake yang keberadaannya lebih menarik perhatian masyarakat Indonesia untuk mempelajari tarian tersebut.

Di tengah kondisi yang memprihatinkan, dimana terjadi pengikisan nilai-nilai kebudayaan lokal seperti diatas, di Kabupaten Ponorogo

\section{Tujuan dan Manfaat Penelitian}

Tujuan penelitian ini sebagai berikut:

1. Untuk mengungkap sejarah perkembangan Tari Kang Potro di Desa Banyudono Kecamatan Ponorogo Kabupaten Ponorogo pada tahun 2006-2012.

2. Untuk mengetahui peranan Tari Kang Potro dalam melestarikan nilainilai budaya lokal di Desa Banyudono ada salah satu kesenian daerah yang sampai sekarang masih dikembangkan dan dilestarikan, yaitu Tari Kang Potro yang mengisahkan dua tokoh abdi dalem pada zaman kerajaan di Ponorogo, bernama Potro Joyo dan Potro Tolo. Sebagai abdi dalem, Potro memiliki komitmen dan kepatuhan yang tinggi dalam melayani semua kebutuhan Sang Raja.

Sejalan dengan eksistensi Tari Kang Potro sebagai kesenian daerah yang sampai saat ini masih terus dijaga dan dilestarikan dalam masyarakat, maka menarik untuk diadakan penelitian tentang peranan Tari Kang Potro dalam melestarikan nilai-nilai budaya lokal (Studi Kasus di Desa Banyudono Kecamatan Ponorogo Kabupaten Ponorogo Pada Tahun 20062012).

Kecamatan Ponorogo Kabupaten Ponorogo pada tahun 2003-2012.

3. Untuk mengetahui upaya masyarakat Desa Banyudono Kecamatan Ponorogo Kabupaten Ponorogo dalam melestarikan Tari Kang Potro di daerah Ponorogo pada tahun 2003-2012.

Penelitian ini diharapkan dapat bermanfaat bagi berbagai pihak, diantaranya :

1. Bagi Program Studi Pendidikan Sejarah FPIPS IKIP PGRI Madiun, 
hasil penelitian ini dapat berguna sebagai literatur kajian sejarah lokal untuk penelitian lebih lanjut.

2. Bagi masyarakat Ponorogo, penelitian ini berguna untuk memberikan informasi kepada masyarakat tentang kesenian lokal bangsa Indonesia yang harus dijaga dan dilestarikan.

3. Bagi Pemerintah Kabupaten Ponorogo, hasil penelitian ini dapat dijadikan bahan untuk mengambil kebijakan dalam pelestarian dan pengembangan kebudayaan di tingkat lokal.

\section{Tinjauan Pustaka}

\section{A. Seni Tari}

Menurut Taylor (dalam Alo Liliweri, 2007: 125) "Seni dipandang sebagai sebuah proses yang melatih keterampilan, aktivitas manusia untuk menyatakan atau mengkomunikasikan perasaan atau nilai yang dimiliki manusia". Pada dasarnya manusia menciptakan suatu karya seni untuk memenuhi kebutuhan akan keindahan sebagai kesatuan hubungan yang terdapat antara penyerapan-penyerapan indera manusia (Joko Tri Prasetyo, dkk, 1998: 77). Kebutuhan ini muncul disebabkan adanya sifat dasar manusia yang ingin mengungkapkan jati dirinya sebagai makhluk yang bermoral, berakal, dan berperasaan. Dalam memenuhi kebutuhan estetik ini, kesenian menjadi bagian integral yang tak terpisahkan dengan kebudayaan. "Kesenian adalah salah satu unsur penyangga kebudayaan, tumbuh dan berkembang menurut kondisi dari kebudayaan itu" (Umar Kayam, 1981:15).

Berdasarkan Ensiklopedi Tari (1980: iii) "kesenian tidak lebih dari perwujudan nilai-nilai yang menjadi pedoman bagi pola tingkah laku anggota masyarakat pendukungnya". Pendapat yang sama disampaikan Nooryan Bahari (2008:45) bahwa kesenian merupakan unsur pengikat yang mempersatukan pedomanpedoman bertindak yang berbeda menjadi suatu desain yang utuh, menyeluruh, dan operasional, serta dapat diterima sebagai sesuatu yang bernilai. Sebagai makhluk yang mempunyai cita rasa tinggi, manusia menghasilkan berbagai corak kesenian mulai dari yang sederhana hingga perwujudan kesenian yang kompleks.

Merujuk pada pengertian tentang kesenian di atas, dapat 
disimpulkan bahwa setiap masyarakat mengembangkan kesenian, salah satunya adalah merupakan ungkapan rasa estetik, sesuai dengan pandangan, aspirasi, kebutuhan, dan gagasan yang melingkupinya. Memang bisa dikatakan bahwa kesenian adalah suatu kebutuhan, tetapi kebutuhan terhadap seni pertunjukkan bisa dikategorikan menjadi tiga, yaitu: kebutuhan untuk memenuhi upacara ritual, kebutuhan untuk menikmati sajian estetis, dan kebutuhan saluran untuk berekspresi ( Soedarsono, 1986: 91).

Hasil karya buatan manusia boleh dikatakan akan menjadi karya seni bila mempunyai nilai estetis, sebab setiap karya seni memang diciptakan untuk dinikmati nilai estetisnya. Suatu hasil seni dapat dikatakan indah apabila rangkaian dari bagianbagiannya merupakan suatu susunan yang lengkap dan merupakan keutuhan, yang mampu menimbulkan kenikmatan (Rohiman Notowidagdo, 2002: 88). Penikmatan tersebut untuk memperoleh kesenangan, kepuasan, dan kelegaan emosional manusia.
Menghargai dan memahami karya seni adalah penting, karena memahami karya seni suatu masyarakat berarti memahami aktivitas vital masyarakat yang bersangkutan dalam momennya yang paling dalam dan kreatif (Rafael Raga Maran, 2000: 104). Selain itu adanya karya seni juga merupakan salah satu energi pendorong perkembangan/dinamika masyarakat dan kebudayaannya melalui unsur-unsur yang terkandung pada karya seni tersebut. Dengan demikian suatu karya seni selalu bersifat sosial tidak saja melambangkan kehadiran seniman yang menciptakannya melainkan melambangkan juga kehadiran masyarakat dimana seniman itu berada dan berkarya.

Adapun tari menurut Katarina Indah S. (2006: 11) dapat didefinisikan sebagai sebuah bahasa yang menyampaikan pesan bukan melalui komunikasi verbal namun melalui ekspresi gerak tubuh. Sedangkan Hutchinson (dalam Oho Garha 1998: 35) berpendapat bahwa tari merupakan gerakan tubuh yang ritmis dan indah sebagai upaya 
penciptaan seseorang dalam memberi bentuk konkret dan kreatif kepada ungkapan perasaanya. Nilai atau makna keindahan pada tari lebih dititik beratkan adanya keselarasan atau kesesuaian antara sejumlah gerak dan rangkaian gerak yang diungkapkan dengan tuntututan dan tujuan dari tarian itu sendiri. Disisi lain F.X Widaryanto (2004: xi) mengutarakan bahwa tari merupakan bentuk seni yang bersifat elusif (tidak mudah dipahami) dan memiliki lapis-lapis simbol yang tidak jarang sangat pekat.

Mengacu dari beberapa pendapat di atas dapat ditarik benang merah bahwa tari merupakan seni yang berasal dari ekspresi hasrat manusia akan keindahan, dimana di dalamnya terdapat simbol-simbol berupa pesan yang dituangkan melalui gerak anggota tubuh yang teratur dan berirama sesuai dengan musik pengiringnya.

Tarian selalu dikaitkan dengan musik, karena tarian dan musik dapat menggambarkan suasana atau konteks kegembiraan dan kesedihan (Alo Liliweri, 2007: 127). Selain itu tarian juga selalu berhubungan dengan seni visual, karena gerakan dalam tarian cara penghayatannya menggunakan indera penglihatan, demikian pula dengan tata rias dan kostumnya.

Unsur dasar estetik pada tari ada gerak khususnya, namun dalam bentuk-bentuk penyajian tari tertentu yang mengambil peranan penting dalam mewujudkan bentuk-bentuk di atas pentas, penari biasanya menggunakan benda-benda untuk mendukung penampilannya, seperti kostum yang memperluas jangkauan gerak penari ataupun properti-properti pentas yang digerakkan oleh penari.

Melalui tarian sebagai salah satu bentuk kesenian, sebenarnya orang dapat memperkokoh nilainilai dan memperkembangkan, mempersatuakan, mempertajam pengertian kita akan nilai-nilai yang secara simbolis diperagakan dengan gerakan yang indah (dalam Ensiklopedi Tari Seri A-E, 1980: iv).

\section{B. Nilai-Nilai Budaya}

Definisi nilai menurut Cheng dalam Elly $M$, Kama, dan Ridwan (2007: 120) merupakan "sesuatu yang potensial, dalam arti terdapatnya hubungan yang harmonis dan kreatif, sehingga 
berfungsi untuk menyempurnakan manusia, sedangkan Lasyo berpendapat bahwa nilai bagi manusia merupakan landasan atau motivasi dalam segala tingkah laku atau perbuatannya. Hal yang sama dikemukakan oleh Taliziduhu Ndraha (2005: 30) bahwa nilai menunjukkan arti atau guna, Jadi setiap yang mengandung arti atau guna bagi pelaku budaya dan bagi lingkungannya tertentu disebut bernilai.

$$
\text { Berdasarkan uraian }
$$

tersebut dapat disimpulkan nilai adalah sesuatu yang bermanfaat dan dianggap penting bagi kehidupan manusia dalam masyarakat, yang selalu dijunjung tinggi sebagai acuan dalam bertindak. Sesuatu dikatakan memiliki nilai apabila berguna dan berharga. Misal: nilai kebenaran, nilai estetika, nilai moral dan nilai religius.

Nilai dalam hal ini memberikan kontribusi bagi perilaku masyarakat pendukungnya, dengan kata lain nilai mempunyai hubungan yang erat dengan manusia, baik dalam bidang etika yang mengatur kehidupan manusia dalam kehidupan sehari-sehari, maupun bidang estetika yang berhubungan dengan persoalan keindahan yang bersumber pada unsur perasaan manusia. Keindahan dalam artian ini menyangkut pengalaman estetik seseorang dalam hubungannya dengan segala sesuatu yang diserapnya.

Nilai-nilai budaya merupakan "konsep-konsep yang hidup di alam pikiran sebagian besar masyarakat mengenai apa yang mereka anggap bernilai, berharga, dan penting dalam hidup, sehingga dapat berfungsi sebagai pedoman yang memberi arah dan orientasi pada kehidupan warga masyarakat" (Sujarwa, 2001:12). Pendapat yang sama ditegaskan oleh Deddy Mulyana dan Jalaludin Rakhmat (2003:27) "nilai-nilai budaya adalah seperangat aturan terorganisasikan untuk membuat pilihan-pilihan dan mengurangi konflik dalam masyarakat", dengan demikian nilai-nilai budaya merupakan pandangan hidup manusia dalam masyarakat yang menegaskan perilaku-perilaku mana yang penting dan perilakuperilaku mana yang harus dihindari.

$\begin{array}{ccc}\text { Orientasi nilai } & \text { budaya } \\ \text { berasal/bersumber dari } & \text { konsep }\end{array}$


value, sebagaimana dikatakan oleh

C. Kluckhohn (dalam Amri Marzali, 2005: 115) "sebuah nilai adalah sebuah konsepsi, eksplisit atau implisit, yang khas milik seorang individu atau suatu kelompok, tentang yang seharusnya diinginkan yang mempengaruhi pilihan yang tersedia dari bentukbentuk, cara-cara, tujuan-tujuan, dan tindakan". Karena nilai berfungsi mengatur satu sistem tindakan, maka nilailah yang menempatkan suatu hal, suatu ucapan, atau tindakan tersebut kedalam satu tempat, apakah diterima atau ditolak oleh masyarakat.

\section{Metode Penelitian}

\section{A. Tempat dan Waktu Penelitian}

Penelitian ini dilakukan di Desa Banyudono Kecamatan Ponorogo Kabupaten Ponorogo. Dipilihnya tempat ini sebagai lokasi penelitian karena di Desa Banyudono terdapat sanggar Tari Aglar yang mengembangkan dan melestariakan berbagai tarian khas daerah Ponorogo, salah satunya ialah Tari Potro. Waktu yang digunakan dalam penelitian ini adalah lima bulan, dari bulan Pebruari sampai dengan bulan Juni tahun 2013.

\section{B. Pendekatan dan Jenis Penelitian}

Pendekatan dalam penelitian ini adalah pendekatan kualitatif. Penelitian kualitatif ditujukan untuk memahami fenomena-fenomena sosial dari sudut pandang partisipan. Dengan demikian, penelitian kualitatif ialah penelitian yang digunakan untuk meneliti pada kondisi objek alamiah dimana peneliti merupakan instrumen kunci (Sugiyono, dalam Trianto, 2010: 179).

Penelitian kualitatif lebih berorientasi pada pendekatan fenomenologi. Menurut Bogdan dan Biklen (dalam Asmadi Alsa, 2004: 33) penelitian dengan pendekatan fenomenologi berusaha memahami makna dari suatu peristiwa dan saling pengaruhnya dengan manusia dalam situasi tertentu, sedangkan jenis penelitian yang digunakan adalah penelitian studi kasus. Emzir (2011: 20) berpendapat studi kasus adalah suatu penelitian yang berusaha menemukan makna, menyelidiki proses, dan memperoleh pengertian serta pemahaman yang mendalam dari individu, kelompok, atau situasi.

\section{Sumber Data Penelitian}


Sumber data yang digunakan dalam penelitian ini berasal dari Sumber Data Primer dan Sekunder. Data Primer yaitu data langsung dari sumber pertama tentang masalah yang diungkapkan (Hadari Nawawi, 2005: 80). Sumber pertama dari penelitian ini berupa hasil wawancara dari pemilik dan anggota Sanggar Tari Aglar, masyarakat Desa Banyudono, tokoh masyarakat serta perangkat desa. Data Sekunder adalah data yang diperoleh dari tangan kedua atau fihak lain, tidak langsung diperoleh oleh peneliti dari subjek penelitiannya (Saifuddin Azwar, 2004: 91). Sumber data sekunder yang digunakan dalam penelitian ini adalah dokumen dan arsip. Dokumen dan arsip yang dimaksud berupa bahan tertulis ataupun foto, untuk keperluan pengabadian suatu peristiwa.

\section{Sampel dan Teknik Pengambilan} Sampel

$$
\begin{aligned}
& \text { Sampel yang digunakan } \\
& \text { dalam penelitian ini adalah } \\
& \text { Pengurus Sanggar Tari Aglar, tokoh } \\
& \text { masyarakat, dan Perangkat desa } \\
& \text { setempat dengan pertimbangan } \\
& \text { mereka memiliki pengetahuan } \\
& \text { mendalam tentang sejarah } \\
& \text { perkembangan Tari Kang Potro dan }
\end{aligned}
$$

peranannya dalam melestarikan nilai-nilai budaya lokal di Desa Banyudono. Teknik pengambilan sampel yang dipilih menggunakan snowball sampling (bola salju).

\section{E. Teknik Pengumpulan Data}

Teknik pengumpulan data merupakan cara mengumpulkan data yang dibutuhkan untuk menjawab rumusan masalah penelitian (Juliansyah Noor, 2011: 138). Penerapan Teknik pengumpulan data dalam penelitian ini agar dapat menghasilkan data yang lengkap. Adapun teknik pengumpulan data tersebut adalah teknik observasi sistematis, interview (wawancara) tak berstruktur dan dokumen tertulis/arsip.

Wawancara dilakukan pada pemilik Sanggar Tari Aglar, anggota paguyuban sanggar tari tersebut, sebagian masyarakat Desa Banyudono, perangkat desa, serta tokoh masyarakat setempat. Observasi dilakukan terhadap Sanggar Tari Aglar dan proses latihan Tari Kang Potro.

\section{F. Teknik Keabsahan Data}

Teknik pengujian keabsahan data dalam penelitian ini menggunakan teknik Triangulasi. Triangulasi dalam penelitian 
kualitatif diartikan sebagai pengujian keabsahan data yang diperoleh dari berbagai sumber, metode, dan waktu (Trianto, 2010: 294). Triangulasi yang digunakan di sini adalah triangulasi sumber dan Triangulasi teknik. Triangulasi Sumber dilakukan dengan cara mengecek data yang telah diperoleh dari sumber data yang satu dengan sumber data yang lain, dalam hal ini sumber yang diperoleh dari pengurus sanggar Tari Aglar, perangkat desa dan sebagian masyarakat Desa Banyudono dibandingkan dan dianilisis sampai mendapatkan suatu kesimpulan yang sama, sedangkan Triangulasi Teknik dilakukan untuk menguji kredibilitas data dengan cara membandingkan teknik pengumpulan data yang satu dengan teknik pengumpulan data yang lain, meliputi data yang diperoleh melalui wawancara dibandingkan dengan data hasil observasi, atau hasil analisis dokumen.

\section{G. Teknik Analisis Data}

Analisis data dalam penulisan ini menggunakan analisis interaktif tiga komponen. Tiga komponen utama tersebut adalah
(1) Reduksi data, (2) Sajian data,

(3) Penarikan simpulan serta verivikasinya (Miles dan

Hubermen, 1992: 16-19).

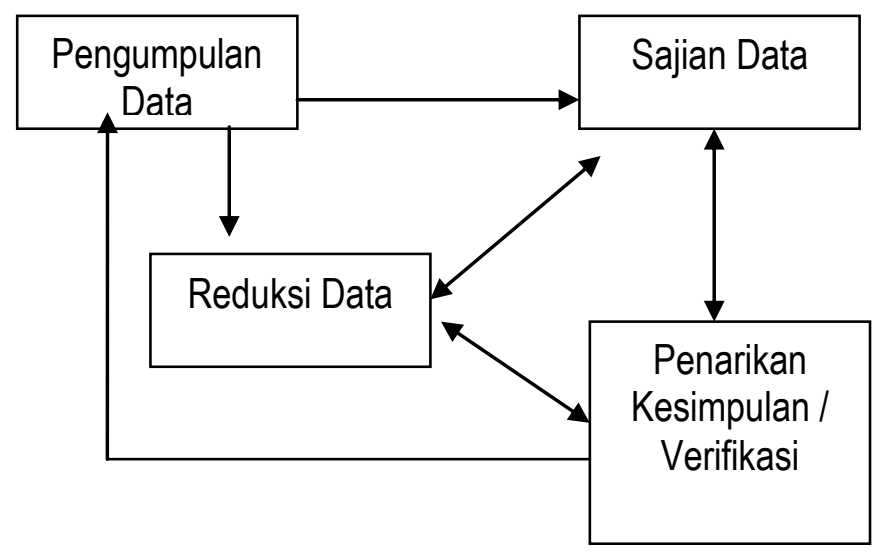

Bagan 3.1: Analisis Kualitatif Model Interaktif (Miles dan Hubermen, 1992:20)

Data mentah yang

terkumpul di lokasi penelitian hasil dari wawancara maupun observasi ditulis dengan rapi,terperinci, dan sistematis setiap selesai mengumpulkan data. Selanjutnya dilakukan reduksi data, yaitu pemilihan hal-hal pokok yang sesuai dengan fokus penelitian, pemusatan perhatian pada penyederhanaan catatan-catatan tertulis di lapangan. Temuan di lapangan yang telah direduksi kemudian dilakukan penyusunan data dengan membuat sajian data berupa rakitan kalimat yang disusun secara logis dan sistematis, sehingga mudah dibaca dan disajikan. Dari penyajian data 
tersebut akan ditemukan pokokpokok temuan yang penting. Temuan-temuan tersebut dijadikan acuan dalam menarik kesimpulan. Simpulan perlu diverivikasi agar hasil penelitian benar-benar dapat dipertanggung jawabkan.

\section{Hasil Penelitian}

\section{A. Gambaran Umum Kelurahan Banyudono}

\section{Keadaan Geografis}

Kelurahan Banyudono merupakan salah satu wilayah yang terletak di Kecamatan Ponorogo Kabupaten Ponorogo dengan ketinggian 95 meter di atas permukaan laut dan memiliki curah hujan 821 $\mathrm{mm} /$ tahun. Topografi wilayah Banyudono berupa dataran yang memiliki luas 89, 851 Ha berdasarkan penggunaannya. Batas wilayah Kelurahan tersebut meliputi: sebelah utara berbatasan dengan kelurahan Keniten, di sebelah selatan Mangkujayan, sebelah Barat Mangkujayan dan Tamanarum, dan di sebelah timur Nologaten dan Bangunsari. Jarak Kelurahan dengan pusat pemerintahan 2 $\mathrm{km}$, jadi secara geografis letak Kelurahan ini sangat strategis.

\section{Keadaan Demografi}

Jumlah penduduk Kelurahan Banyudono mengalami peningkatan dari tahun sebelumnya. Hal ini dibuktikan dengan Jumlah penduduk tahun lalu 4.934 jiwa, sedangkan jumlah penduduk tahun ini meningkat menjadi 4.989 jiwa, terdiri dari jumlah penduduk laki-laki 2.451 jiwa, dan jumlah penduduk perempuan 2.538. Dari keseluruhan jumlah penduduk tersebut terdapat 1.443 kepala keluarga.

\section{B. Latar Belakang Keberadaan Sanggar Tari Aglar}

Sanggar Seni "Aglar Dance Company" berada di Kelurahan Banyudono, Kecamatan Ponorogo, Kabupaten Ponorogo, tepatnya di Jl. Madura No. 32C. Pendiri dari Sanggar Tari ini adalah Bapak Shodig Pristiwanto S.Sn karena keinginannya yang besar untuk ikut berperan aktif dalam usaha mengembangkan dan melestarikan kesenian tradisional Reyog pada khususnya, dan seni budaya tradisional yang berkembang di Kabupaten Ponorogo pada 
umumnya. Disebut sebagai Sanggar Aglar Dance Company dikarenakan dalam Sanggar itu sendiri terdapat pengkhususan julukan dalam Sanggar Tari (privat tradisi), Sanggar Reog beserta Karawitan Reog, dan juga Sanggar Reog anakanak.

Sebagai kelompok (Organisasi Kesenian), Aglar Dance Company dari beberapa kegiatan yang sudah dihasilkan, bertekad untuk bisa menyumbangkan hasil karya seni dan mencetak kaderkader seniman tidak hanya di Desa Banyudono tetapi juga di Kabupaten Ponorogo. Selain itu dengan dedikasi penuh Sanggar Tari ini berusaha untuk membantu mewujudkan Ponorogo sebagai kabupaten yang mempunyai nilai dan potensi Pariwisata khususnya di Bidang Seni Budaya.

Bidang yang dikerjakan di Sanggar ini mengajarkan kesenian Reog Ponorogo dan juga beberapa tarian tradisi lain, seperti: Tari Lebur Sakethi, Tari Kang Potro, dan Tari Klonol. Di dalam sanggar sendiri juga masih terdapat bidang Karawitan iringan Reog yang menjadi satu naungan dengan Reog Sanggar Aglar Dance Company yang diberi nama "Singo Aglar
Nuswantoro", selain itu terdapat pula Reog Anak bernama "Caroko Mudo", namun untuk hal tari tradisi lain hanya bernamakan Sanggar Aglar Dance Company.

C. Asal Usul Tari Kang Potro dan Perkembangannya dari Tahun 2006-2012

Reog Ponorogo sebagai sebuah kesenian tradisional khas Ponorogo dewasa ini semakin berkembang, baik di wilayah Kabupaten Ponorogo maupun di luar Kabupaten Ponorogo. Sebagai sebuah kesenian yang digemarai masyarakat di tanah Jawa, kesenian Reog mengalami berbagai macam perkembangan terutama dalam hal penyajiannya.

Pertunjukan Reog sebelum tahun 80-an dalam penyajiannya, selain tari Dadhak Merak, Bujangganong, Jathilan , dan Klono Sewandono, tokoh Potro Joyo-Potro Tholo (Penthul-Tembem) juga terdapat dalam pertunjukan Reog, namun seiring berjalannya waktu tokoh Potro Joyo dan Potro Tholo dalam pementasan Reog di Ponorogo mulai tidak ditampilkan lagi dalam Festival Reog Nasional setiap perayaan grebeg Suro, kecuali pada waktu pertunjukan Reog versi Bantarangin setiap dua 
bulan sekali yang di dalamnya masih ada tokoh tersebut.

Sebenarnya tokoh Potro Joyo dan Potro Tolo yang ada dalam kesenian Reog pada waktu dulu mempunyai karakter yang tarinya tidak digarap, karena pengekspresian tokoh tersebut hanya berjalan saja tanpa ada suatu gerakan apapun. Berawal dari cerita itulah melahirkan suatu karya tari baru, yang diberi nama Tari Kang Potro pada tahun 2003, namun pendokumentasiannya dikaitkan dengan peristiwaperistiwa sosial yang terjadi di masyarakat, jadi secara karakteristik tidak murni dari cerita Potro Joyo dan Potro Tolo itu saja. Pada pengkaryaan tari ini tokoh Potro Joyo dan Potro Tolo digambarkan sebagai abdi dalem Raden Pujangga Anom dari Kerajaan Kediri yang menyamar di Bantarangin. Kang Potro diposisikan menjadi pekatek (pemelihara kuda). Sebagai seorang pekatek mereka mempunyai sifat jenaka, gembira, semangat kerja, dan patuh pada perintah majikan.

Penciptaan Tari Kang Potro ini sebagi upaya untuk mengangkat fenomena dua tokoh itu pada sebuah garapan tari yang disesuaikan dengan kehidupan nyata di masyarakat sebagai gambaran sosok masyarakat kecil yang menjunjung tinggi nilai-nilai kebersamaan/gotong royong, ceria, dan bekerja tanpa pamrih. Kang Potro ditarikan oleh tujuh orang penari putra dengan ketentuan utama penari harus mempunyai watak yang humoris agar bisa menari secara total sesuai dengan karakter tokoh tersebut.

Karakter tarinya yang unik, dibantu dengan koreografinya yang tertata secara jelas serta irama rasa musikalitasnya yang enak didengar mencerminkan nuansa daerah Ponorogo, membuat tarian ini sangat entertain, tidak menjenuhkan meskipun sudah pernah melihatnya. Inilah yang menyebabkan tari Kang Potro disukai oleh banyak orang terutama di kalangan masyarakat Ponorogo.

D. Peranan Tari Kang Potro dalam Melestarikan Nilai-Nilai Budaya Lokal

Hadirnya Tari Kang Potro di lingkungan kehidupan masyarakat menjadi sebuah media komunikasi dalam wujud gerak untuk menyampaikan pesan atau maksud tertentu berupa nilai-nilai yang terkandung dalam karya tersebut. 
Tari sebagai bentuk seni tidak hanya sebagai ungkapan gerak, tetapi juga membawa serta nilai rasa irama yang mampu memberikan sentuhan estetis bagi orang-orang yang melihatnya sebagai salah satu karya seni.

Penciptaan Tari Kang Potro selain memperhatikan aspek-aspek estetis juga mempertimbangkan nilai dan norma-norma yang berlaku di masyarakat, sehingga tarian ini mampu dicerna oleh semua kalangan masyarakat, baik seniman maupun masyarakat biasa yang tidak mempunyai latar belakang di senipun bisa merasakan tarian tersebut. Selain itu karena konsep tariannya yang sangat sederhana sebagai sebuah gambaran sosok masyarakat kecil "Wong Cilik" membuat masyarakat menggemari tarian ini.

Nilai-nilai budaya lokal yang terkandung dalam Tari Kang Potro meliputi Nilai Kebersamaan/Gotong Royong, Nilai Kejujuran, Nilai Kesederhanaan, Bekerja Tanpa Pamrih, dan Mengabdi pada atasan/Loyalitas yang Tinggi.

Di Kelurahan Banyudono apabila diamati nilai-nilai tersebut keberadaanya mulai memudar dari masyarakat seiring dengan terjadinya perubahan sosial. Nilainilai budaya lokal mencerminkan sikap mental yang harus dimiliki oleh masyarakat, baik sebagai individu maupun anggota masyarakat, sehingga harus terus dijaga dan dilestarikan. Salah satu upaya penanaman nilai-nilai budaya lokal tersebut melalui penciptaan Tari Kang Potro sebagai sebuah karya tari berupa gambaran keadaan sosial masyarakat pada waktu itu, yang di dalamnya terkandung nilai-nilai yang harus di junjung tinggi oleh masyarakat setempat. Melalui tarian tersebut memberikan pemahaman pada masyarakat betapa pentingnya nilai-nilai yang telah mengakar dan berkembang sejak zaman dahulu sebagai ciri khas budaya yang dimiliki masyarakat setempat, dengan demikian Tari Potro sangat berperan dalam melestarikan nilainilai budaya lokal di Kelurahan Banyudono, mengingatkan kembali pada masyarakat akan keberadaan nilai-nilai tersebut sebagai kaidahkaidah yang mengatur kepentingan hidup pribadi maupun kepentingan hubungan antar manusia. 
E. Upaya Masyarakat Desa Banyudono dalam Melestarikan Tari Kang Potro

$$
\begin{aligned}
& \text { Masyarakat memiliki } \\
& \text { peranan yang sangat penting dalam } \\
& \text { melestarikan Tari Kang Potro. } \\
& \text { Pelestarian Tarian ini terus } \\
& \text { diupayakan sampai sekarang, } \\
& \text { karena dianggap masih berguna } \\
& \text { dan relevan dengan kehidupan } \\
& \text { masyarakat. Upaya masyarakat } \\
& \text { dalam melestarian Tari Potro dapat } \\
& \text { dilakukan melalui berbagai cara, } \\
& \text { yaitu: }
\end{aligned}
$$

dalam menyampaikan materi Tari Kang Potro.

5. Dari Pemerintah Kabupaten Ponorogo sendiri juga memberikan wadah untuk berekspresi dalam kegiatan pentas yang diselenggarakan setiap malam bulan purnama di alun-alun.

6. Mengikutkan Tari Kang Potro dalam event-event baik lokal maupun regional supaya masyarakat lebih mengenal tarian ini secara mendalam untuk membantu mewujudkan Ponorogo sebagai kabupaten yang mempunyai nilai dan potensi pariwisata khususnya di bidang Seni Budaya.

\section{Pembahasan}

\section{A. Sejarah Perkembangan Tari} Kang Potro Tahun 2006-2012

Kang Potro merupakan
sebuah Tarian tradisional
Kabupaten Ponorogo yang memiliki
nilai historis tersendiri bagi
masyarakat Ponorogo, karena
dalam penciptaannya merupakan
sebuah kreatifitas pengangkatan
kembali seni budaya tradisional
dengan berakar pada budaya
Ponorogo khususnya kesenian


Reog) yang disesuikan dengan kondisi sosial pada waktu itu.

Pertunjukan Reog Ponorogo sebelum tahun 80-an dalam penyajiannya selain Tari Dadhak Merak (Singo Barong), Bujangganong (Penthulan), Jathilan, dan Klana Sewandana, juga terdapat tokoh Penthul-Tembem yang dalam penampilannya memakai topeng berkarakter gecul/lucu, dua tokoh ini juga sering disebut dengan Potro JoyoPotro Tholo yang karakter tarinya tidak digarap (tidak berpola) karena pengekspresian tokoh tersebut hanya berjalan saja sebagai pengiring atau pelawak. Kang Potro merupakan sebutan dari tokoh Potro Joyo-Potro Tholo. Peran Potro Joyo-Potro Tholo dalam satu versi merupakan penggambaran tokoh abdi dari Kerajaan Daha (Kediri) pengikut Raden Pujangga Anom (Bujangganong) yang menyamar di Kerajaan Bantarangin, dalam penyamarannya Kang Potro digambarkan sebagai figur seorang Pekathik (pemelihara kuda). Penyamaran Potro Joyo-Potro Tholo ke Bantarangin beserta Raden Pujangga Anom bertujuan untuk memantau kekuatan dan mencari tahu rahasia kesaktian Prabu Klono Sewandono yang konon sangat ditakuti dan disegani oleh raja-raja tetangganya.

Versi lain berdasarkan cerita Reog menceritakan bahwa Pujangga Anom adalah patih dari Prabu Klono Sewandono (seorang raja Bantarangin) Pada waktu itu Prabu Klono Sewandono jatuh cinta kepada Dewi Sekartaji, putri raja Kediri yang sudah dipertunagkan dengan Panji Asmorobangun dari Jenggala. Demi kepentingannya, Klono Sewandono memerintahkan Pujangga Anom untuk melamar Dewi Sekartaji. Kebarangkatan Pujangga Anom dari Bantarangin diiringi oleh prajurut kuda yang dinamakan Jathilan atau Reog (Djoko Surjo, Soedarsono, Djoko soekiman, 1985: 59).

Jika dilihat dari dua versi cerita di atas ceritanya sangat berlawanan dan tidak bisa disatukan, namun ini semua hanyalah pijakan sebuah cerita dari sudut pandang masing-masing penulis pada waktu itu, dalam Tari Kang Potro yang ingin ditonjolkan juga bukanlah dari sisi cerita aslinya tetapi lebih mengarah pada pengangkatan nilai-nilai kegotongroyongan, kesederhanaan 
dan pengabdian yang tulus dari seorang abdi.

Seiring berjalannya waktu tokoh Potro Joyo-Potro Tholo dalam pementasan Reog di Ponorogo jarang sekali ditampilkan dalam Festival Reog Nasional setiap perayaan grebeg Suro, kecuali pada waktu pertunjukan Reog versi Bantarangin setiap dua bulan sekali yang di dalamnya masih ada tokoh tersebut. Hal ini disebabkan karena peranan mereka yang kurang penting dalam pertunjukan Reog.

Berdasarkan cerita di atas dan juga melihat potensi serta semakin hilangnya kedua tokoh Potro Joyo-Potro Tholo dalam pertunjukan Reog, Tari Kang Potro diciptakan oleh Bapak Shodig Pristiwanto pada tahun 2003 dalam rangka mengikuti Pekan Budaya Jawa Timur di Batu Malang mewakili Kabupaten Ponorogo dan berhasil memperoleh prestrasi juara satu penata tari terbaik. Pada bulan Desember tahun 2003 Tari Kang Potro menjadi wakil propinsi Jawa Timur untuk mengikuti Festival Tari di Taman Mini Indonesia Indah Jakarta. Prestasinya sangat baik pada waktu itu meraih empat penghargaan sekaligus, sebagai Penata Tari,
Iringan, Rias Busana, dan Penyaji Unggulan

Melihat beberapa prestasi yang pernah diraih pada waktu itu, pada tahun 2004 Tari Kang Potro diajukan untuk meraih hak intelektual/hak cipta sebagai hasil karya dari Bapak Shodig. Pengajuan hak cipta dibantu oleh Dinas Pendidikan dan Kebudayaan Jawa Timur untuk direkomendasikan ke Jakarta.

Selama kurun waktu 20062007, dalam perkembangannya tarian ini sering diundang untuk dipentaskan dalam beberapa acara di Jawa Timur, diantaranya Tari Kang Potro pernah menjadi bagian dalam penggarapan tari pembukaan Festival Tari dan Pekan Budaya Jawa Timur berpadu dengan tari-tarian lain di Gedung Grahadi Surabaya. Pada upacara pembukaan MTF (Majapahit Travel Fair) dan Festival Seni Cak Dur Rashim Tari Kang Potro juga tampil untuk mengisi acara di Surabaya.

Dari Pemerintah Ponorogo sendiri, juga menyambut baik dan mendukung keberadaan Tari Kang Potro, dibuktikan pada waktu itu Tarian ini tampil sebagai bagian pada tari pembukaan FRG (Festival Reog Nasional) di Alon-alon 
Ponorogo. Tidak hanya itu saja, Tari

Potro juga diminta Bupati

Ponorogo H. Amin, S.H untuk dimassalkan oleh anak-anak TK di alun-alun Ponorogo, dengan jumlah peserta 8.000.000 lebih, namun belum berhasil meraih Museum Rekor Indonesia (MURI).

Pada tahun 2008, karena karakteristiknya cukup menarik dan warna Ponorogonya sangat kuat terlihat dari segi iringan yang berangkat dari Kesenian Reog dan semangat gotong-royong yang terkandung dalam tarian itu, membuat Tari Potro disusun ulang untuk dijadikan materi Taman Kanak-Kanak (TK) se-Kabupaten Ponorogo dan disetujui oleh Bupati. Agar materi ini bisa disampaikan secara jelas kepada guru maupun peserta didik dibuat pendokumentasian berupa rekaman CD yang dikomersialkan untuk kalangan sendiri dengan tuntunan sekalian, kemudian dilanjutkan menggunakan iringan dan peraganya langsung.

Tarian ini memang sangat dikenal di dunia pendidikan, pada tahun 2009 SMKN 9 Surabaya sebanyak 10 siswa jurusan Tari melakukan Praktek Kerja Lapangan di Sanggar Tari Aglar selama 2 minggu, disana para siswa diberi pelatihan tentang tari Potro dan ditampilkan di SMKN 9 Surabaya pada waktu acara pentas seni. Hasilnya tarian tersebut juga menjadi salah satu bahan ajar di sana.

Kegagalan meraih rekor MURI pada tahun 2006 tidak menjadikan Bupati jera untuk menampilkan Tari Potro lagi, tahun 2011 Bupati meminta agar Potro ditampilkan massal lagi oleh anakanak dari 500 TK di Kabupaten Ponorogo. Kali ini Tari Kang Potro berhasil Tercatat dalam Museum Rekor Indonesia (MURI) dengan dua kategori. Pertama, jumlah penari yang paling banyak di Indonesia mencapai 10.269 anak. Kedua, orisinalitas tari yang lengkap secara kostum dan gerakan. untuk kategori Tarian dengan peserta tari terbanyak dengan jumlah penari 10.269 orang.

Perkembangan Tari Kang Potro hingga tahun 2012 semakin baik, walaupun secara edukatif tidak diharuskan menjadi materi muatan lokal tetapi banyak sekolah yang memakai Tari Potro sebagai bahan ajar karena medianya tercukupi dengan adanya kaset 
audiovisual sebagai panduan dalam berlatih. Pada tahun ini pula Tari Kang Potro diundang untuk tampil mewakili Jawa Timur lagi di anjungan Jawa Timur Taman Mini Indonesia Indah.

Masyarakat umum pada saat ini melihat Tari Potro begitu fenomenal tidak hanya di lingkup Ponorogo tetapi Jawa Timur bahkan Nasional melihat Potro sebagai sebuah pergerakan warna tari baru yang menginspirasi munculnya karya-karya tari lain dengan bernuansa/bertema lucu setelah Potro menjadi wakil Jawa Timur dalam parade Tari Daerah di TMII. Misalnya: Tari Si Ganyong dari Banyuwangi, Rung Sarung dari Pacitan, dan Cangik dari Yogyakarta.

B. Peranan Tari Kang Potro dalam Melestarikan Nilai-Nilai Budaya lokal di Desa Banyudono Kecamatan Ponorogo Kabupaten Ponorogo Tahun 2006-2012.

Penciptaan suatu karya seni tidak bisa dipisahkan dari lingkungan/kehidupan yang ada disekelilingnya dan berbagai peristiwa alam yang telah terjadi, maka dalam penciptaanya selalu memunculkan nilai-nilai yang dianut oleh masyarakat setempat.
Nilai-nilai tersebut hidup di alam pikiran sebagian besar warga masyarakat sebagai pedoman dalam bertindak. Tari Kang Potro merupakan kesenian daerah yang mampu bertahan sampai saat ini, karena dalam penyajiannya tidak hanya berlandaskan pada aspekaspek estetis, tetapi juga mempertimbangkan nilai-nilai yang berlaku dalam masyarakat. Selain itu tradisi/budaya yang ada dalam masyarakat Ponorogo, dijadikan inspirasi dalam pengembangan koreografi Tari Kang Potro, sehingga memberi warna tersendiri pada wujud tarian ini.

Adapun nilai-nilai budaya lokal yang terkandung dalam Tari Kang Potro terinspirasi dari gambaran sosok masyarakat kecil, yang erat dengan nilai-nilai sebagai berikut:

a. Nilai Kebersamaan/Gotong Royong

Gotong royong merupakan proses cooperation yang terjadi dalam masyarakat, dimana proses ini menghasilkan tolong-menolong dan pertukaran tenaga serta barang maupun pertukaran emosional dalam bentuk timbal balik diantara mereka (Burhan 
Bungin, 2006:59). Unsur kebersamaan dalam Tari Kang Potro terlihat pada gerakan mengangkat krenjang secara bersama-sama kemudian saling ditukarkan dengan penari yang lain, setelah itu krenjang dikumpulkan menjadi satu.

b. Nilai Kejujuran

Di dalam masyarakat Jawa terdapat ungkapan yang berbunyi sing jujur mujur "orang jujur akan beruntung”. Orang yang tidak berlaku jujur lamakelamaan akan mengalami kehancuran, karena diketahui kebohongannya (Sri Retna, Tashadi, Wahyudi, 1996: 272) . Hal ini juga terdapat dalam Tarian Kang Potro yang menceritakan bahwa tokoh Potro Joyo dan Potro Tholo adalah abdi yang bekerja secara tulus dan jujur. Meskipun Kang Potro hanya sebagai abdi dalem mereka berani melaporkan adipati maupun senopati kepada Raja apabila berbuat salah. Kebiasaan berkata jujur adalah cerminan orang yang bermartabat dan disenangi oleh banyak orang. rakyatnya. c. Nilai Kesederhanaan

Sebagai abdi dalem Kang Potro hidup dengan kesederhanaan yang didasari oleh sikap rendah hati, sanggup membawa diri sesuai dengan keadaan dirinya, dengan kemampuannya dan dengan keadaan masyarakat sekitarnya. Kesederhanaan merupakan pola pikir dan pola hidup yang yang proporsional, tidak berlebihan, dan mampu menggunakan apa yang dimiliki untuk hal-hal yang bermanfaat.

d. Bekerja Tanpa Pamrih

Unsur bekerja tanpa pamrih terlihat pada tokoh Kang Potro yang selalu ceria dalam bekerja, meskipun hanya sebagai abdi dalem mereka mampu menjalankan tugasnya dengan baik, tulus, tanpa memikirkan imbalan yang didapat. Hendaknya dalam bekerja nilai ini harus diterapkan, karena dengan adanya ketulusan dan keikhlasan dalam melaksanakan pekerjaan, maka akan mendapatkan imbalan tersendiri, namun apabila bekerja menjadikan materi sebagai tujuan utama, maka 
akan terjebak dalam pengejaran yang tidak berkesudahan.

e. Mengabdi pada atasan/Loyalitas yang Tinggi Nilai loyalitas tercermin pada sikap Kang Potro yang setia, patuh, dan taat pada majikan. Hal ini menginspirasi masyarakat agar mempunyai loyalitas yang tinggi dalam bekerja. Dengan loyalitas yang tinggi menumbuhkan rasa cinta dan tanggung jawab terhadap pekerjaan, sehingga selalu berusaha memberikan pelayanan dan perilaku yang terbaik (mengabdikan diri) pada atasan.

Nilai-nilai budaya lokal inilah yang membedakan antara tarian suatu daerah dengan daerah lainnya. Nilai ini pula yang sekaligus memberikan identitas terhadap tarian tersebut, berkaitan dengan pesan moral yang ingin disampaikan dari penampilan suatu karya tari. Keberadaan nilai-nilai tersebut dari tahun ke tahun mulai melemah dalam ranah kehidupan sehari-hari masyarakat Kelurahan Banyudono, seiring terjadinya perubahan sosial akibat adanya pengaruh globalisasi yang kian cepat dalam menyebarluaskan teknologi dan informasi.

Masyarakat Banyudono merasa sangat dimudahkan dengan teknologi maju yang ada pada masa sekarang ini, membuat mereka kadang-kadang lupa akan dirinya sebagai mahluk sosial, sehingga rasa kesatuan batin antar anggota masyarakat mulai berkurang. Contoh konkritnya: Ketika ada salah satu anggota masyarakat yang mempunyai hajatan dan membutuhkan pertolongan, apabila tidak didatangi di rumah untuk dimintai tolong, mereka tidak mau secara sukarela datang untuk membantu, terutama ketika tidak mendapat manfaat apapun dari pertolongannya. Selain itu dalam hal perbaikan jalan, jembatan, dan fasilitas umum lainnya, sikap gotong-royong yang terbina dalam masyarakat sudah tidak terlalu kuat, sebagian masyarakat memilih untuk mengutamakan kepentingan pribadinya dari pada harus meluangkan waktunya untuk bergotong-royong demi kepentingan bersama.

Keberadaan Tari Kang Potro dalam kondisi ini, tidak hanya berperan sebagai tontonan (media hiburan) yang indah dan menarik, 
namun juga bisa menjadi sarana penyebaran informasi efektif untuk mendidik masyarakat dalam melestarikan nilai-nilai budaya lokal yang telah mengakar lama dalam masyarakat. Nilai-nilai budaya lokal yang terkandung dalam tarian tersebut mampu dicerna oleh semua kalangan masyarakat, baik seniman maupun masyarakat biasa yang tidak mempunyai latar belakang di senipun bisa merasakan makna nilai yang terkandung didalamnya. Secara langsung Tari Kang potro berperan dalam mensosialisasikan dan menanamkan kembali pada masyarakat nilai-nilai budaya lokal yang keberadaanya semakin tersisihkan, sehingga tumbuh kesadaran pada masyarakat betapa pentingnya keberadaan nilai-nilai tersebut untuk mengatur kehidupan bersama dalam masyarakat ditengah arus globalisasi yang melanda negara ini. Dengan demikian melalui tarian sebagai salah satu bentuk kesenian, sebenarnya orang dapat memperkokoh, mengembangkan, dan memperkuat nilai-nilai budaya lokal yang secara simbolis diperagakan dengan gerakan yang indah. Hal ini tentu membuat

masyarakat Banyudono tidak kehilangan jati dirinya sebagai warga masyarakat yang menjunjung tinggi nilai gotongroyong, tolong-menolong, jujur, dan bekerja tanpa pamrih. Nilai-nilai yang hadir dalam setiap tarian inilah, yang akan tertanam pada relung hati setiap penari maupun penontonnya.

C. Upaya Masyarakat dalam Melestarikan Tari Kang Potro di Desa Banyudono Kecamatan Ponorogo Kabupaten Ponorogo Pada Tahun 2006-2012.

Kehadiran kesenian
terbentuk atas dasar dukungan
masyarakat dalam membentuk
serta menciptakan kesenian baru
sebagai suatu upaya pemenuhan
kebutuhan yang dimiliki oleh
masyarakat. Tari Kang Potro hadir
memberikan identitas/ciri khas
tersendiri bagi pergerakan warna
tari yang bertema lucu/gecul. Tema
tari seperti ini jarang sekali ada,
sehingga masyarakat merasa
sangat terhibur dan menerima baik
keberadaan tarian tersebut, namun
terkadang pengetahuan masyarakat
masih kurang mengenai makna
yang terkandung dalam Tari Kang
Potro. Penciptaan tari ini berawal
dari keterbatasan kemampuan


kepenarian di Ponorogo, yang pada waktu keadaan penarinya masih belum rata. Dari keterbatasan itu melahirkan karya tari yang materi geraknya sederhana, tidak terlalu teknis tapi secara konsep (alur cerita) bisa langsung mengena di hati masyarakat, karena mengangkat sosok masyarakat kecil yang kental dengan nilai-nilai kebersamaan, sederhana, ceria, dan seakan tanpa pamrih dalam bekerja. Nilai-nilai tersebut dianggap masih berguna dan relevan dengan kehidupan masyarakat. Selain itu nuansa Ponorogonya yang kuat berakar dari kesenian Reog, membuat Tari Kang Potro terus dilestariakan sampai sekarang ini.

Peran pemerintah serta masyarakat sangat diharapkan guna menjaga kelestarian tarian ini. Pengembangan Tari Kang Potro pada awalnya hanya dilakukan melalui Sanggar Tari Aglar yang didirikan oleh Bapak Shodig di Kelurahan Banyudono Kecamatan Ponorogo Kabupaten Ponorogo. Melalui sanggar ini masyarakat Banyudono mengikutsertakan putra-putrinya menjadi anggota sanggar untuk mempelajari Kesenian Reog dan berbagai tarian daerah Ponorogo. Kelurahan Banyudono sendiri, selain memberi kesempatan anggota sanggar untuk mengenalkan Tari Kang Potro pada masyarakat melalui kegiatankegiatan di Kelurahan, seperti: acara rapat kelurahan, karang taruna, dan lain-lain. Kelurahan juga memberikan fasilitas tempat latihan tari di Kantor Kelurahan Banyudono untuk anak-anak dan pemuda disana. Latihan biasanya dilaksanakan pada hari Minggu sore dan Jum'at malam, jadi selain di sanggar latihan tari juga dilakukan di Kantor Kelurahan. Generasi muda dalam hal pelestarian ini, memegang peranan yang penting, karena pada diri generasi muda tersimpan potensi yang besar dan memiliki daya kreatifitas yang tidak terbatas untuk membangun suatu masyarakat ke arah yang lebih baik lagi.

Upaya pewarisan Tari Kang Potro tidak hanya dilakukan oleh masyarakat Kelurahan Banyudono, tetapi Pemerintah Kabupaten Ponorogo juga berperan dalam pelestariannya, dengan cara mengenalkan tarian ini sejak usia dini, melalui pelatihan yang diberikan kepada seluruh Guru TK 
se-Kabupaten

Ponorogo.

Pemerintah juga meminta agar tarian ini ditarikan secara masal oleh anank-anak TK pada acara perayaan Grebeg Suro tahun 2011. Hasilnya Tari Kang Potro berhasil tercatat di Museum Rekor Indonesia, dengan jumlah penari paling banyak di Indonesia dan orisinalitas tari yang lengkap secara kostum dan gerakan. Selain itu pada tahun 2012/2013, Pemerintah juga membuat event atraksi tari sebagai wadah untuk berekspresi masyarakat, yang diselenggarakan setiap malam bulan purnama di alun-alun. Tarian-tarian yang berasal dari semua sanggar di Ponorogo mendapatkan giliran untuk pentas, salah satunya Sanggar Tari Aglar yang mementaskan Tari Kang Potro.

Pengenalan Tari Kang Potro sejak usia dini, dilakukan dalam rangka menumbuhkan rasa cinta terhadap budaya daerah pada anakanak. Karakter mencintai seni dan budayanya sendiri adalah faktor yang penting untuk menciptakan masyarakat yang berbudi luhur dalam tindakan dan pikiran sebagai refleksi dari kepribadiannya.

Sampai saat ini masyarakat sangat antusias dalam mengembangkan Tari Kang Potro, hal ini dibuktikan dengan dipakainya Tari Kang Potro sebagai materi ajar, tidak hanya ditingkat TK, namun di tingkat SD, SMP, dan SMA. Untuk sumber acuan dalam pengajaran, Tari Kang Potro didokumentasikan dalam bentuk CD yang disertai dengan tuntunan dan iringannya langsung. CD tersebut tidak dijual secara bebas, hanya untuk koleksi sanggar dan media pengajaran di sekolahsekolah. Tari Kang Potro juga sering diikutkan dalam event-event baik lokal maupun regional supaya masyarakat lebih mengenal tarian ini secara mendalam, sehingga nilai-nilai budaya lokal yang terkandung di dalamnya mampu dimaknai dan diterapkan dalam kehidupan bermasyarakat. Dari berbagai kegiatan pelestarian yang telah dilakukan secara dinamis, diharapkan akan membentuk suatu kesadaran kultural yang terdapat pada setiap masyarakat Banyudono.

\section{Simpulan}

Secara historis, nama Tari Kang Potro berasal dari nama tokoh Potro Joyo-Potro Tholo, dimana dalam ceritanya merupakan dua orang abdi pengikut Pangeran Pujangga Anom, 
yang menjalankan tugas penyamaran ke

Kerajaan Bantarangin, dalam penyamarannya Kang Potro digambarkan sebagai seorang Pekathik (pemelihara kuda). Dari tahun ke tahun keberadaan Tari Kang Potro semakin berkembang. Mulai dari dijadikan materi untuk anak-anak TK seKabupaten Ponorogo, pendokumentasian dalam bentuk CD, hingga berhasil tercatat dalam Museum Rekor Indonesia dengan jumlah penari terbanyak di Indonesia dan orisinalitas tari yang lengkap secara kostum serta gerakan.

Keberadaan Tari Kang Potro, tidak hanya berperan sebagai tontonan (media hiburan) yang indah dan menarik, namun juga bisa menjadi sarana penyebaran informasi efektif untuk mendidik masyarakat dalam menanamkan kembali nilai-nilai budaya lokal yang keberadaannya mulai memudar seiring perkembangan zaman. Hal ini menumbuhkan kesadaran masyarakat betapa pentingnya mengembangkan dan melestarikan tarian ini, sebagai upaya menjaga budaya bangsa dari pengaruh budaya asing

Upaya pelestrian Tari Kang Potro dilakukan oleh berbagai pihak, baik masyarakat maupun pemerintah melalui beberapa cara diantaranya mendirikan Sanggar sebagai tempat pelestarian dan pengembangan tari, memperkenalkan Tarian ini dalam setiap kegiatan kelurahan, dan mengikutkan Tari Kang Potro dalam event-event baik lokal maupun regional. Melalui upaya-upaya tersebut dapat memperkokoh eksistensi Tari Kang Potro, sebagai budaya lokal yang erat dengan nilai-nilai kehidupan masyarakat kecil.

\section{Saran}

Berdasarkan hasil penelitian yang telah dilakukan adapun saran yang dapat dipertimbangkan yaitu:

1. Bagi masyarakat Banyudono

Kesadaran masyarakat untuk menjaga dan melestarikan Tari Kang Potro perlu ditingkatkan, karena masih ada sebagian masyarakat yang melihat Tari Kang Potro dari sisi kelucuannnya saja tanpa mampu memaknai nilai-nilai apa saja yang terkandung dalam tarian tersebut.

2. Bagi Sanggar Tari Aglar

Hendaknya lebih cermat lagi dalam mendokumentasikan momentmoment penting penampilan Tari Kang Potro dalam berbagai festival yang pernah diikuti, sehingga dapat dijadikan sumber acuan mengenai perkembangan Tari Kang Potro dari tahun ke tahun. 
3. Bagi Pemerintah Kelurahan

Banyudono

Pemerintah harus berperan lebih aktif lagi dalam melestarikan Tari Kang Potro melalui pembinaanpembinaan pada masyarakat tentang kesenian khas daerah yang wajib dilestarikan sebagai warisan budaya lokal.

4. Bagi Pemerintah Kabupaten Ponorogo

Pemerintah daerah hendaknya tidak hanya mewajibkan Tari Kang Potro untuk dijadikan bahan ajar di tingkat TK saja, tapi juga di tingkat SD, SMP, dan SMA.

\section{Daftar Pustaka}

Abraham Nurcahyo, dkk. 2009. Ilmu Sosial dan Budaya Dasar. Magetan: Lembaga Edukasi Swastika.

Alo Liliweri. 2007. Dasar-Dasar Komunikasi Antarbudaya. Yogyakarta: Pustaka Pelajar.

Amri Marzali. 2005. Antropologi dan Pembangunan Indonesia. Jakarta: Kencana.

Asmadi Alsa. 2004. Pendekatan Kuantitatif dan Kualitatif serta kombinasinya dalam penelitian Psikologi. Yogyakarta: Pustaka Pelajar.

Ayu Sutarto. 2004. Menguak Pergumulan antara Seni, Politik, Islam, dan Indonesia. Jember:
Kelompok Peduli Budaya dan Wisata Daerah Jatim.

Bambang Widianto dan Iwan Meulia P (Eds.). 2009. Perspektif Budaya. Jakarta: Rajawali Pers.

Burhan Bungin. 2006. Sosiologi Komunikasi, Teori, Paradigma, dan Diskusi Teknologi Komunikasi di Masyarakat. Jakarta: Kencana.

Deddy Mulyana dan Jalaludin Rakhmat. 2003. Komunikasi AntarBudaya. Bandung: PT Remaja Rosdakarya.

Djoko Surjo, dkk. 1985. Gaya Hidup Masyarakat Jawa di Pedesaan: Pola Kehidupan Sosial-Ekonomi dan Budaya. Jakarta: Depdikbud.

Elly M. Setiadi, dkk. 2007. Ilmu Sosial dan Budaya Dasar. Jakarta: Kencana.

Emzir. 2011. Metodologi Penelitian Kualitatif. Jakarta: Rajawali Pers.

Hadari Nawawi. 2005. Metode Penelitian Bidang Sosial. Yogyakarta: Gadjah Mada University Press.

Joko Tri P, dkk. 1998. Ilmu Budaya Dasar. Jakarta: PT Rineka Cipta.

Juliansyah Noor. 2011. Metodologi Penelitian Skripsi, Tesis, Disertasi, dan Karya Ilmiah. Jakarta: Kencana.

Katarina Indah S. 2006. Notasi Tari. Surakarta: ISI Press.

Koentjaraningrat. 1990. Pengantar Ilmu Antropologi Edisi Baru. Jakarta: PT Rineka Cipta.

Miles, Matthew B. dan Huberman, A. Michael. 1992. Analisis Data 
Kualitatif. (terjemahan Tjetjep

Rohendi R.). Jakarta: UI Press.

Nooryan Bahari. 2008. Kritik Seni. Yogyakarta: Pustaka Pelajar.

Oho Garha. 1998. Pokok-Pokok Pengajaran Kerajinan Tangan dan Kesenian. Jakarta: Departemen Pendidikan dan Kebudayaan.

Proyek Penelitian dan Pencatatan Kebudayaan Daerah. 1980. Eksiklopedi Tari Indonesia Seri AE. Jakarta: Departemen Pendidikan dan Kebudayaan.

Rafael Raga Maran. 2000. Manusia dan Kebudayaan dalam Perspektif Ilmu Budaya Dasar. Jakarta: PT Rineka Cipta.

Rohiman Notowidagdo. 2002. Ilmu Budaya Dasar Berdasarkan AlQur'an dan Hadits. Jakarta: PT Raja Grafindo Persada.

Saifuddin Azwar. 2004. Metode Penelitian. Yogyakarta: Pustaka Pelajar.
Soedarsono (Ed). 1986. Kesenian, Bahasa, dan Folklor Jawa. Yogyakarta: Departemen Pendidikan dan Kebudayaan.

Sri Retna Astuti, dkk. 1996. Unsur-Unsur Nilai Budaya dalam Serat Witaradya. Jakarta: Departemen Pendidikan dan Kebudayaan RI.

Sujarwa. 2001. Manusia dan Fenomena Budaya Menuju Perspektif Moralitas Agama. Yogyakarta: Pustaka Pelajar.

Taliziduhu Ndraha. 2005. Teori Budaya Organisasi. Jakarta: PT Rineka Cipta.

Trianto. 2010. Pengantar Penelitian Pendidikan Bagi Pengembangan Profesi Pendidikan dan Tenaga Kependidikan. Jakarta: Kencana.

Umar Kayam. 1981. Seni, Tradisi, Masyarakat. Jakarta: PT Djaya Pirusa.

Widaryanto, F.X. 2005. Kritik Tari, Gaya, Struktur, dan Makna. Bandung: Kelir. 